\title{
Discussion about Insulin Role in Diabetes Treatment
}

\section{Amos G* \\ Department of Theology, Zefat Academic College Kibbutz Eilon, Israel}

*Corresponding author: Amos Gelbard, Department of Theology, Zefat Academic College Kibbutz Eilon, Galil Maaravi, Israel, Tel: +972 1-800-344-544, Email: amosgelbard@gmail.com

\section{Opinion}

Volume 2 Issue 3

Received Date: August 04, 2017

Published Date: August 10, 2017

DOI: $10.23880 /$ doij-16000161

\section{Opinion}

Diabetes type2 transpires from having too much sugar in the bloodstream to the point that sugar reaches the urine.

This situation is usually treated with Insulin, the hormone responsible for the transfer of sugar from the bloodstream to fat or muscle. This however leads to several illnesses.

For example Alzheimer's disease prevalence in Diabetes type 2 patients may be related to the Insulin based treatment [1]. Diabetes patients treated with Metformin, a drug which doesn't contain Insulin, showed normal rates of Alzheimer's prevalence which actually led to this drug being tested for its role against $\mathrm{AD}$ [2]. And treatment of Alzheimer's disease with the hormone opposing Insulin's action, Glucagon, actually shows very promising results [3-5].

Insulin treatment also leads to Diabetics gaining more and more weight.

Sugar in the urine, while hallmark for diabetes, can also be the body's natural way of disposing of the sugar.

Therefore it makes sense to reconsider the use of Insulin based treatment and perhaps turn the attention of Diabetes2 treatment to focus more on just diet and exercise.

\section{References}

1. Amos Gelbard (2017) Rethinking Glucose Role in Alzheimer's Disease Based on the Disease Incidence in Diabetes Type 2 Patients'. J Gerontol Geriatr Res 6: 414 .

2. Hundal RS1, Krssak M, Dufour S, Laurent D, Lebon $\mathrm{V}$, et al. (2000) 'Mechanism by Which Metformin Reduces Glucose Production in Type 2 Diabetes', Diabetes 49(12): 2063-2069

3. Gejl M, Gjedde A, Egefjord L, Moller A, Soren B, et al. (2016) In Alzheimer's Disease, 6-month treatment with GLP-1 analog prevents decline of brain glucose metabolism: Randomized, placebo-controlled, double-blind clinical trial. Front Aging Neurosci 8: 108.

4. Bak AM, Egefjord L, Gejl M, Steffensen C, Stecher CW, et al. (2011) Targeting amyloid-beta by glucagon-like peptide-1 (GLP-1) in Alzheimer's disease and diabetes. Expert Opin Ther Target 15(10): 1153-1162.

5. Gault VA, H ölscher C (2008) GLP-1 agonists facilitate hippocampal LTP and reverse the impairment of LTP induced by beta-amyloid. Eur J Pharmacol 587(1-3): 112-117. 